\title{
APLIKASI BAFFLED CHANNEL SEBAGAI ALTERNATIF OPTIMASI PENGOLAHAN KUALITAS AIR
}

\author{
Yogi Irmas Pratama ${ }^{1)}$ dan Maulita Prygel Nursiana ${ }^{2)}$ \\ ${ }^{1)}$ Mine Planning Department, PT Kaltim Prima Coal \\ ${ }^{2)}$ Environment Department, PT Kaltim Prima Coal
}

\begin{abstract}
ABSTRAK
Air limpasan (runoff) pada area pertambangan terbuka umumnya memiliki tingkat kekeruhan yang tinggi dan/atau bersifat asam, sehingga memerlukan pengolahan sebelum memasuki badan air penerima. Pengolahan aktif merupakan metode yang efektif untuk diterapkan, dimana terdapat tahapan pengadukan cepat yang bertujuan salah satunya untuk pencampuran bahan kimia. Studi pustaka ini bertujuan melihat potensi pengaplikasian pengadukan hidrolis menggunakan baffled channel untuk meningkatkan efektivitas. Konfigurasi kolam harus terdiri dari dua bagian atau lebih agar proses dapat berjalan, kolam atenuasi di bagian hulu dan kolam hilir yang dapat berbentuk kolam labirin, meandering. Baffled channel dapat diposisikan pada saluran keluaran (outlet) dari kolam atenuasi. Sebuah pengadukan cepat akan berhasil ketika terpenuhinya gradien kecepatan pengadukan $(\mathrm{G})$ dan waktu detensi (td) yang dipersyaratkan. Parameter yang dapat direkayasa untuk mencapai persyaratan tersebut adalah jumlah sekat (n) yang terdapat di sepanjang saluran. Kalkulasi jumlah sekat yang dibutuhkan harus dapat memenuhi parameter pengadukan pada setiap rentang debit minimum dan maksimum. Tercapainya kriteria pengadukan akan meningkatkan efektivitas tahapan pengolahan selanjutnya.
\end{abstract}

Kata kunci : Pengadukan, baffled channel

\section{ABSTRACT}

Runoff in open pit areas commonly contain high levels of turbidity and/or low level of $\mathrm{pH}$, its requiring processing before entering the environment. Active processing is an effective method to be applied, where there is rapid mixing stage aim to blend chemical substances. The purpose of this literature study is to see potential of applications the hydraulic mixing using baffled channel to increase effectiveness. The configuration of the pond must be consist of two or more compartments in order to the process run well, attenuation pond at the upstream and at downstream pond that can be labyrinth pond or meandering. The baffled channel can be positioned at outlet channel from the attenuation pond. A rapid mix will successful when required gradient of velocity $(G)$ and the detention time (dt) are reached. The parameter can be engineered to meet these requirements are the amount of baffled along the channel. Number of partition needed should be able to meet the wedge parameters at minimum and maximum discharge range. Attaining criteria will increase the effectiveness of the next processing stage.

Keywords: mixing, baffled channel

\section{A. PENDAHULUAN}

Pengolahan kualitas air limpasan (runoff) pada area pertambangan dibutuhkan untuk memastikan kualitas air memenuhi baku mutu yang ditetapkan oleh pemerintah, sebelum memasuki badan air penerima. Pengolahan dibutuhkan mengingat kualitas air limpasan yang umumnya memiliki tingkat kekeruhan yang tinggi dan/ atau memiliki nilai $\mathrm{pH}$ yang rendah (bersifat asam). Pengolahan kualitas air dapat dikelompokkan menjadi pengolahan aktif dan pengolahan pasif. 
Pengolahan aktif merupakan metode yang efektif untuk diterapkan pada pertambangan terbuka. Hal ini mengingat besarnya kuantitas air yang harus diolah, sehingg sulit diperoleh waktu tinggal yang panjang. Pada pengolahan aktif terdapat tahapan koagulasi atau pengadukan cepat yang bertujuan untuk pencampuran bahan kimia (sebagai koagulan dan/ atau untuk penurunan tingkat kesadahan) dengan air yang diolah, sehingga kontaminan dapat terpisahkan dan terendapkan pada tahapan pengendapan.

Faktualnya pada pengolahan kualitas air sulit diperoleh kondisi optimal untuk menciptakan keberhasilan pengadukan yang efisien. Kondisi kontur pada fasilitas pengolahan tidak selalu memungkinkan terciptanya tenaga pengadukan yang proper untuk sebuah keberhasilan pengadukan. Dampak langsung yang timbul dari kondisi ini adalah penggunakan bahan kimia yang tidak efisien. Selanjutnya, ketidak efisienan ini akan lanjut menimbulkan dampak terbentuknya banyak residu bahan kimia pada saluran dan kolam pengendap.

Kondisi ini menuntut adanya instrumen tambahan guna terciptanya pengadukan yang efisien. Studi ini bertujuan melihat potensi pengaplikasian baffled channel (sekat) sebagai salah satu pilihan untuk meningkatkan kefektifan sebuah pengadukan. Penempatan sekat dapat diposisikan pada saluran keluaran (outlet) kolam kontrol debit untuk meningkatkan tenaga pengadukan yang dihasilkan.

\section{B. METODOLOGI}

Studi pada makalah ini dilakukan menggunakan kajian pustaka yang didasarkan pada teori pengadukan. Pengadukan pada suatu pengolahan kualitas air terdiri atas beberapa metode. Analisa untuk setiap pilihan metode berdasarkan kepada keunggulan dan kekurangan masing-masing yang tersedia pada literatur. Pemilihan jenis menyesuaikan dengan kondisi faktual pada fasilitas pengolahan air guna menghasilkan pengolahan yang efisien.

\section{HASIL DAN PEMBAHASAN}

Pengadukan berdasarkan kecepatannya terdiri atas pengadukan cepat dan lambat. Sementara berdasarkan metodenya, pengadukan dapat dibedakan atas tiga jenis :

1. Pengadukan mekanis, adalah metode pengadukan yang menggunakan alat pengaduk berupa impeller yang digerakan dengan motor bertenaga listrik. Umumnya menggunakan pengadukan mekanis yang terdiri dari motor, poros pengaduk dan gayung pengaduk (impeller). Berdasarkan pada bentuknya, dikenal tiga macam impeller, yaitu paddle (pedal), turbine, dan propeller (baling-baling)

2. Pengadukan hidrolis adalah pengadukan yang memanfaatkan gerakan air sebagai tenaga pengadukan. Sistem pengadukan ini menggunakan energi hidrolik yang dihasilkan dari suatu aliran hidrolik. Energi hidrolik dapat berupa energi gesek, energi potensial (jatuhan) atau adanya lompatan hidrolik dalam suatu aliran. Beberapa contoh pengadukan hidrolis adalah terjunan, loncatan hidrolis, baffled channel dll.

3. Pengadukan pneumatic adalah pengadukan yang menggunakan udara (gas) berbentuk gelembung yang dimasukkan ke dalam air, sehingga menimbulkan gerakan pengadukan pada air. Injeksi udara bertekanan ke dalam suatau badan air akan menimbulkan turbulensi, akibat lepasnya gelembung udara ke permukaan air. Makin besar tekanan udara, kecepatan gelembung udara yang dihasilkan makin besar dan diperoleh turbulensi yang juga semakin besar. 
Sebuah pengadukan akan berhasil ketika terpenuhinya gradien kecepatan pengadukan dan waktu detensi yang dipersyaratkan. Kriteria gradien kecepatan dan waktu detensi untuk sebuah pengadukan adalah seperti pada tabel 1 berikut.

Tabel 1. Waktu detensi dan gradien kecepatan

\begin{tabular}{cc}
\hline Waktu Pengadukan, td (detik) & Gradien Kecepatan, G (detik $\left.{ }^{-\mathbf{1}}\right)$ \\
\hline 20 & 1000 \\
30 & 900 \\
40 & 790 \\
$\geq 50$ & 700 \\
\hline
\end{tabular}

Pengadukan mekanis merupakan jenis yang umum digunakan untuk mendapatkan nilai gradien kecepatan yang dibutuhkan untuk sebuah pengadukan cepat, khususnya pada pengolahan kualitas air yang bukan berasal dari limpasan kegiatan pertambangan. Pengadukan hidrolis merupakan alternatif yang paling memungkinkan untuk dimanfaatkan pada area pertambangan. Hal ini karena pengadukan memanfaatkan energi hidrolik yang terdapat pada aliran air sebagai tenaga pengadukan dan tidak memerlukan sumber energi tambahan, sehingga proses jadi lebih efisien.

Terdapat beberapa pilihan pengadukan hidrolis yang dapat diaplikasikan. Namun terjunan dan loncatan hidrolis memiliki ketergantungan terhadap kondisi kontur, dimana pilihan ini memerlukan beda tinggi yang cukup untuk dapat menghasilkan tenaga pengadukan yang dibutuhkan. Sementara faktual di lapangan, tidak semua lokasi pengolahan kualitas air memiliki kontur yang dapat memberikan beda tinggi yang sesuai. Berdasarkan pertimbangan tersebut, baffled channel (sekat) merupakan tipe pengadukan hidrolis yang dapat diaplikasikan pada hampir semua kondisi.

Konfigurasi kolam harus terdiri dari dua bagian atau lebih untuk penerapan metode ini, yaitu kolam atenuasi sebagai pengatur debit pada bagian hulu dan kolam hilir yang dapat berbentuk kolam labirin, meandering atau konfigurasi lainnya. Sekat dapat diposisikan pada saluran keluaran (outlet) dari kolam atenuasi.

Konfigurasi kolam yang dimaksud adalah seperti pada Gambar 1 dan contoh gambaran penempatan sekat pada outlet seperti pada Gambar 2.

Kecepatan sebuah pengadukan dinyatakan dalam gradien kecepatan dengan fungsi sebagai berikut.

$$
G=\sqrt{\frac{W}{\mu}}=\sqrt{\frac{P}{\mu \cdot V}}
$$

dimana :

G : gradien kecepatan $\left(\operatorname{detik}^{-1}\right)$

W : tenaga yang disuplai per satuan volume air $\left(\mathrm{N}-\mathrm{m} / \mathrm{detik}^{\mathrm{m}} \mathrm{m}^{3}\right)$

$\mathrm{P} \quad$ : suplai tenaga ke air (N.m/detik)

$\mathrm{V} \quad$ : volume air yang diaduk, $\mathrm{m}^{3}$

$\mu \quad$ : viskositas absolut air, N.detik $/ \mathrm{m}^{2}$

nilai $\mathrm{P}$ atau suplai tenaga ke air dinyatakan sebagai berikut :

$$
P=Q \cdot \rho \cdot g \cdot h
$$

dimana :

$\mathrm{P} \quad$ : suplai tenaga ke air (N.m/detik)

Q : debit aliran $\left(\mathrm{m}^{3} /\right.$ detik)

$\rho \quad$ : berat jenis $\left(\mathrm{kg} / \mathrm{m}^{3}\right)$

g : percepatan gravitasi $\left(\mathrm{m} / \mathrm{detik}^{2}\right)$

$\mathrm{h} \quad$ : kehilangan energi, head loss (m) 


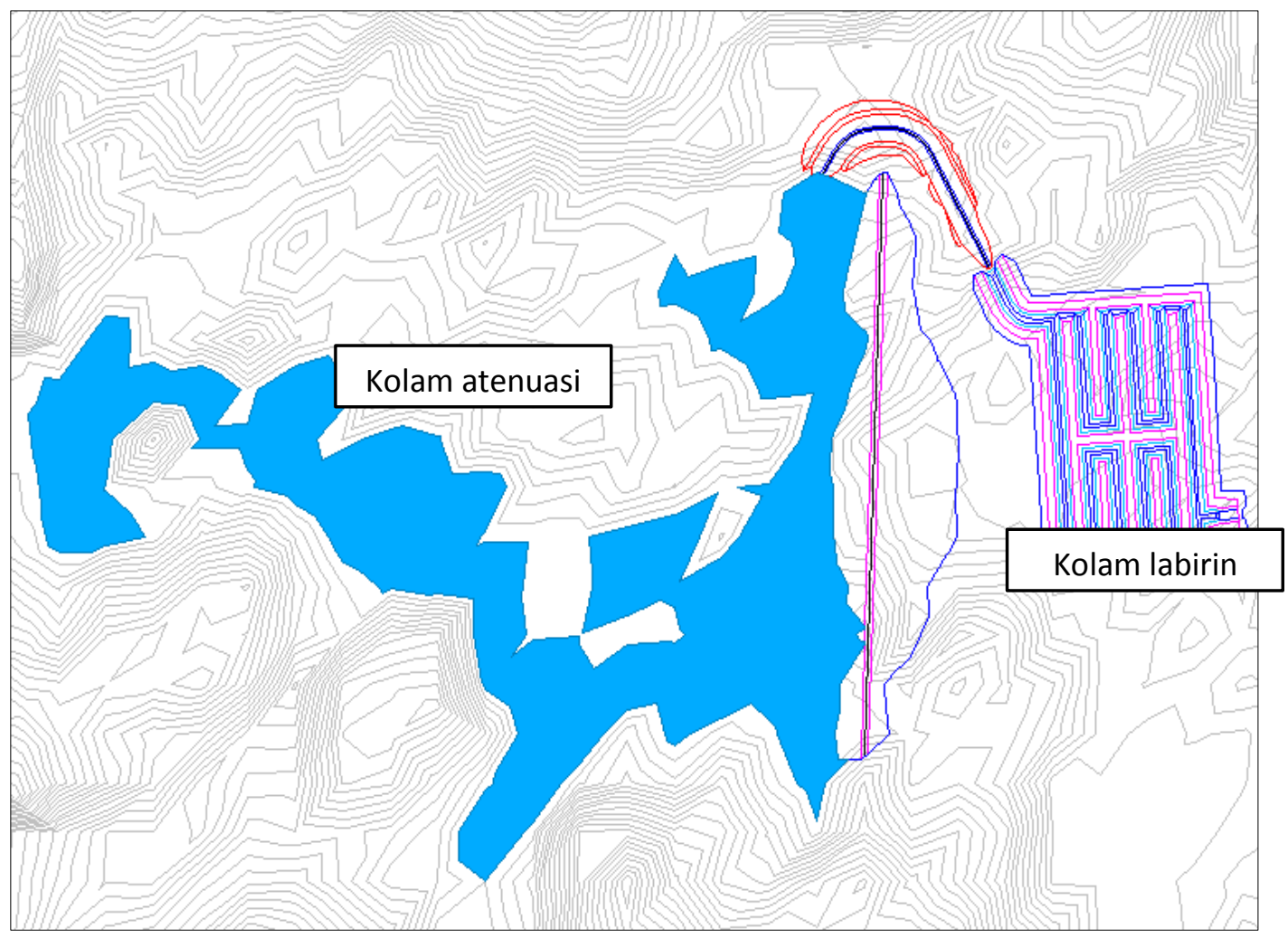

Gambar 1. Contoh layout konfigurasi kolam dengan konfigurasi kolam atenuasi dan kolam labirin

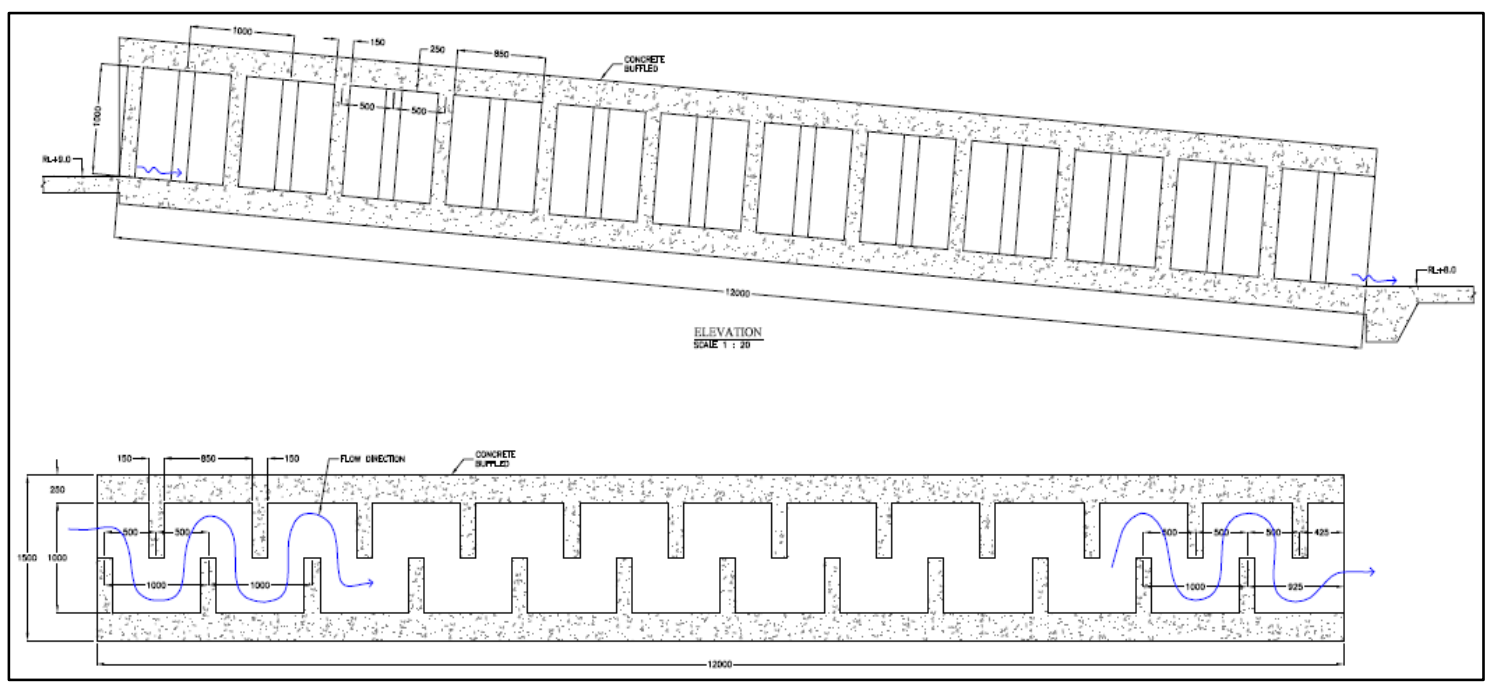

Gambar 2. Penampang outlet kolam atenuasi dengan tambahan sekat di sepanjang saluran

sehingga kombinasi dari persamaan (1) dan persamaan (2) menjadi :

dimana :

$$
G=\sqrt{\frac{g \cdot h}{v \cdot t d}}
$$

$$
\begin{array}{ll}
\text { td } & : \text { waktu detensi (detik) } \\
v & : \text { viskositas kinematis }\left(\mathrm{m}^{2} /\right. \text { detik) }
\end{array}
$$


Berdasarkan persamaan (3) parameter yang dapat direkayasa untuk mencapai nilai $G$ yang dibutuhkan adalah parameter head loss $(h)$, sementara parameter yang lain merupakan konstanta dan ketetapan yang nilai nya sudah baku. Selanjutnya untuk mencapai nilai $h$ yang diinginkan, hal yang dapat dilakukan adalah penambahan sekat $(n)$ di sepanjang saluran.

Jika dibandingkan saluran tanpa sekat dengan saluran yang terdapat sekat, head loss yang dihasilkan akan lebih besar pada saluran yang memiliki sekat. Hal ini disebabkan oleh adanya tambahan hambatan aliran sepanjang saluran selain head loss yang dihasilkan dari gesekan dengan permukaan saluran.

Penambahan sekat di sepanjang saluran akan meningkatkan head loss dan/ atau kecepatan pengaliran, sehingga meningkatkan tenaga pengadukan $(\mathrm{P})$ secara langsung. Berdasarkan persamaan (1) nilai $G$ sebanding dengan nilai $P$, sehingga ketika terjadi peningkatan nilai $P$, maka gradien kecepatan juga akan mengalami peningkatan. Hubungan antara nilai $G$ dan tenaga pengadukan adalah seperti pada gambar 3 berikut.

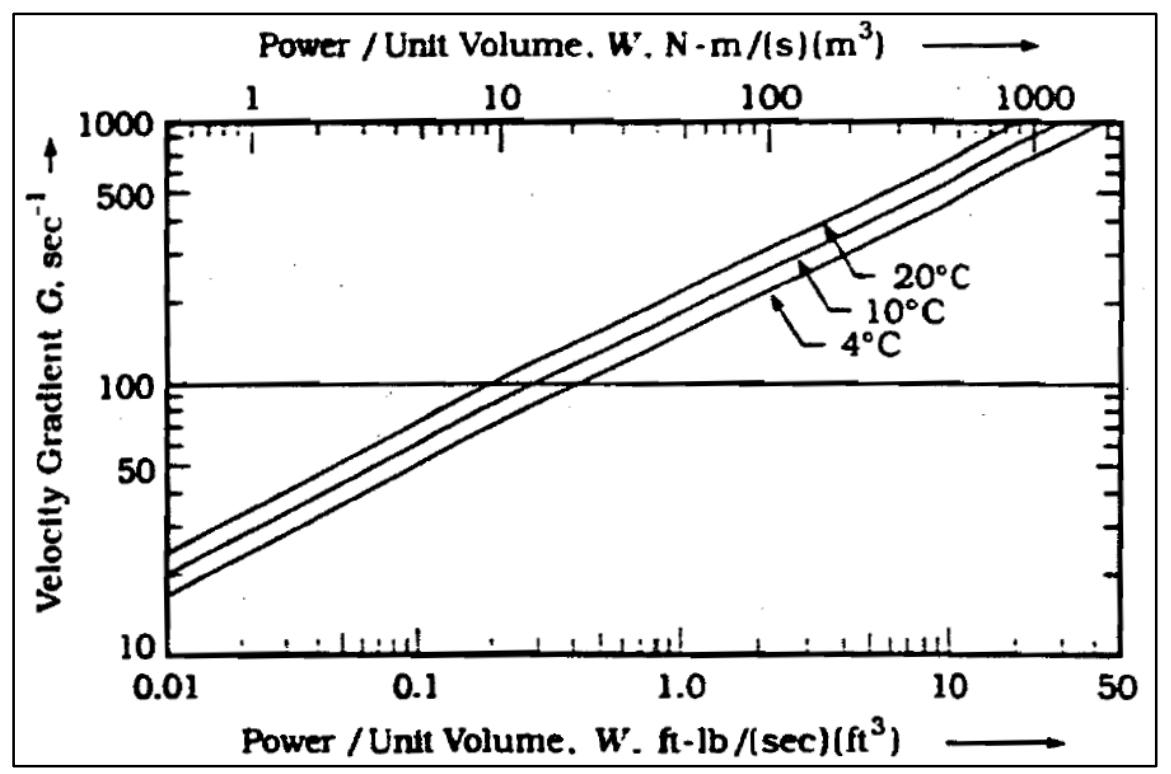

Gambar 3. Kebutuhan tenaga pengadukan

Jumlah sekat yang dibutuhkan pada saluran dipengaruhi oleh debit air yang akan diolah dan dimensi dari saluran. Nilai debit yang diolah dipengaruhi oleh kapasitas outlet, kapasitas kolam atenuasi dan nilai debit yang masuk. Nilai debit yang diolah dan melewati saluran akan berfluktuasi. Kalkulasi jumlah sekat yang dibutuhkan harus dapat memenuhi nilai $\mathrm{G}$ dan $t d$ pada setiap rentang debit minimum dan maksimum.

Nilai debit yang diolah dihitung menggunakan hidrograf satuan sintesis (HSS), dimana hidrograf merupakan penyajian grafis salah satu besaran aliran sebagai fungsi waktu. Hidrograf menunjukkan tanggapan menyeluruh DTA (Daerah Tangkapan Air) terhadap masukan hujan. Hidrograf satuan adalah hidrograf limpasan langsung yang dihasilkan oleh hujan efektif merata di DTA dengan intensitas tetap (diambil $1 \mathrm{~mm} / \mathrm{jam}$ ) dalam satu satuan waktu yang ditetapkan (diambil 1 jam).

Untuk sungai-sungai yang tidak mempunyai hidrograf banjir pengamatan, biasanya digunakan hidrograf-hidrograf sintetis yang telah dikembangkan di negara-negara lain, yang parameternya harus disesuaikan terlebih dahulu dengan karakteristik daerah pengaliran yang ditinjau. Rumus yang digunkan untuk perhitungan Hidrograf Satuan Sintetis (HSS) Nakayasu adalah : 
dimana :

$$
Q p=\frac{c A R o}{3,6(0,3 T p+T 0,3)}
$$

Qp : Qmaks, debit puncak banjir

C : koefesien aliran

A : luas DTA

Ro : hujan satuan

Tp : tenggang waktu dari permulaan hujan sampai puncak banjir

T0,3 : waktu yang diperlukan oleh penurunan debit, dari debit puncak sampai menjadi $30 \%$ dari debit puncak.

Evaluasi keberhasilan dapat dilakukan dengan penegcekan pada keadaan aliran yang terbentuk di sepanjang saluran, dimana keadaan aliran harus turbulen pada kondisi pengadukan cepat. Keadaan aliran dapat dikelompokkan berdasarkan kepada bilangan Reynold, dengan kriteria sebagai berikut:

- Aliran laminar, nilai R kurang dari 500

- $\quad$ Aliran turbulen, nilai R lebih dari 12.500

- Aliran transisi, nilai R berada pada rentang $500-12.500$

Bilangan Reynold sendiri dapat dikalkulasi dengan formula sebagai berikut

$$
R=\frac{V \cdot L}{v}
$$

dimana :

$$
\begin{array}{ll}
\mathrm{R} & \text { : bilangan Reynold } \\
\mathrm{V} & : \text { kecepatan aliran } \\
\mathrm{L} & \text { : panjang karakteristik } \\
\mathrm{V} & \text { : kekentalan kinematik. }
\end{array}
$$

\section{SIMPULAN}

1. Pengaplikasian baffled channel pada outlet kolam atenuasi memungkinkan terjadinya peningkatan nilai gradien kecepatan untuk keberhasilan pengadukan

2. Gradien kecepatan dan waktu detensi merupakan parameter penentu yang harus terpenuhi untuk keberhasilan sebuah pengadukan

3. Head loss $(h)$ adalah parameter yang dapat direkayasa guna mendapatan gradien keceapatan pengadukan yang dipersyaratkan

4. Keberhasilan sebuah pengadukan dapat dilihat berdasarkan gradien kecepatan yang dihasilkan dan kondisi aliran yang tercipta pada saluran

\section{E. SARAN}

1. Studi kasus dalam skala laboratorium atau skala lapangan perlu dilakukan guna melihat tingkat keberhasilan penerapan metode ini

2. Keberhasilan metode ini dapat dilihat dari keadaan aliran yang terbentuk dan faktual tingkat keefektivan pengolahan dibanding tanpa menggunakan metode ini

3. Pemilihan jenis instrumen tambahan untuk meningkatkan tenaga pengadukan tidak hanya terbatas pada baffled channel, namun menyesuaikan dengan kebutuhan dan kondisi faktual pada instalasi pengolahan air 


\section{DAFTAR PUSTAKA}

Chow, Ven Te. 1985. Hidrolika Saluran Terbuka (Open Channel Hidraulic). Penerbit Erlangga : Jakarta

Fair, Geyer and Okun. 1968. Water and Wastewater Engineering, Volume 2, Water Purification and Wastewater Treatment and Disposal. John Wiley \& Sons, inc : New York, London, Sydney.

Limantara, Lily Montarcih. 2010. Hidrologi Praktis. Lubuk Agung : Bandung

Metcalf and Eddy. 2014. Wastewater Engineering, Treatment and Resourc Recovery, Volume 1. Mc Graw - Hill International Edition Singapore

Reynolds, Tom D. 1977. Unit Operation and Processes in Environmental Engineering. Brook/Cole Engineering Division : Monterey, California. 
PROSIDING TPT XXVIII PERHAPI 2019 